\title{
Plasticity on 'BRS 8381' Glycine max (L.) Merril Agronomic Attributes in Different Years of Cultivation in Roraima
}

Oscar José Smiderle

Brazilian Agricultural Research Corporation - Embrapa Roraima, Boa Vista-RR, Brazil.

* CNPq Research Productivity Fellows

E-mail: oscar.smiderle@embrapa.br

Pedro Henrique Santos de Menezes

Federal University of Roraima, UFRR, Campus Cauamé, BR 174, Km 12, Monte Cristo, Boa Vista, RR, Brazil.

E-mail: pedro.agro86@gmail.com

Aline das Graças Souza (Corresponding Author)

Department of Fitotecnia and Environmental Sciences, Federal University of Paraíba, Campus II/Areia-PB, Brazil.

E-mail: souzaufpel@gmail.com

Thiago Jardelino Dias

Department of Agriculture, Federal University of Paraíba, Campus III/Bananeiras-PB, Brazil. E-mail: thiagojardelinodias@gmail.com

\section{Daniel Gianluppi}

Brazilian Agricultural Research Corporation - Embrapa Roraima, Boa Vista-RR, Brazil.

E-mail: daniel.gianluppi@embrapa.br

Received: Feb. 1, 2020

doi:10.5296/jas.v8i2.16682
Accepted: Mar. 12, 2020 Published: Mar. 16, 2020

URL: https://doi.org/10.5296/jas.v8i2.16682 


\section{Abstract}

Soy has high plasticity, which expands its capacity to adapt to different environmental and management conditions, through morphological changes in production components. Thus, the objective was to evaluate the effects of different densities of soybean cultivar BRS 8381 on agronomic characteristics. The experiment was implemented and conducted in a Cerrado area, in the Agua Boa of Embrapa Roraima experimental field. A randomized block design was used in a $2 * 4$ factorial scheme, with four replications. The treatments consisted of two years of soybean cultivation (2015 and 2016), sown in four plant densities (10, 14, 18 and 22 plants per linear meter). Agronomic characteristics were evaluated: plant height; height of insertion of the first pod; stem diameter; number of nodes on the stem; number of pods per plant; number of branches per plant; dry mass of the plant; harvest index and grain yield. The highest average productivity of 'BRS 8381' soybeans in the Cerrado area of Roraima is obtained with a population of 387.448 plants per hectare. 'BRS 8381' plants at density 22 plants $\mathrm{m}^{-1}$ linear are not suitable for the Cerrado conditions of Roraima. The cv. BRS 8381 is influenced by rainfall and temperature factors in the Cerrado conditions of Roraima.

Keywords: Glycine max, agronomic characteristics, plant density, cerrado of Roraima, grain production

\section{Introduction}

The yield of a crop is defined by the interaction between the plant, the production environment and the management of the crop. Among the management practices performed, the choice of cultivar, the sowing time, the spacing used and the density of plants are factors that influence the production components and, consequently, the crop yield (Smiderle et al., 2016).

In the last two decades, the soybean crop has shown significant increases in area and productivity in Brazil. The adjustment in management practices helped to increase the competitiveness of the crop in relation to other large producers, such as the United States of America and Argentina.

However, grain yield, as well as other phenotypic variables, is dependent on the genetic attributes of plants, the production environment and the interaction between these two factors (Prysiazhniuk et al., 2019). In turn, the environment depends on intrinsic characteristics of the region, as the weather, which is not managed by man, and phytotechnical features. To increase the productivity of soybeans, it is necessary to use new techniques and improve those used, especially those that interfere with morphological and production components (Bawa et al., 2019). Among the techniques mentioned, the association of spatial arrangements and plant density has stood out as potential tools for increasing productivity (Nakano et al., 2019).

Within this context, Embrapa Roraima, is indicating the cultivar BRS 8381 for the State of Roraima due to its wide adaptation to the edaphic conditions and greater productivity, expanding the offer of conventional soy cultivars to the Northern region of Brazil (Smiderle et al., 2016). The cultivar BRS 8381 has a semi-determined growth type; upright growth 
habit and open plant architecture, the seed has yellow seed coat color, black imperfect hilum color (Smiderle et al., 2016). Knowing the importance of soybean cultivation in the State of Roraima, the objective was to determine the agronomic performance of the 'BRS 8381' soybean in relation to plant density in the Cerrado of Roraima.

\section{Material and Methods}

The experiment was performed in a Cerrado area, during the years 2015 and 2016, in the Água Boa of Embrapa Roraima experimental field, in the city of Boa Vista-RR, whose geographic reference coordinates are recorded at $02^{\circ} 39^{\prime} 00^{\prime}$ latitude, $60^{\circ} 49^{\prime} 40^{\prime}$ ' longitude and $90 \mathrm{~m}$ altitude. The region's climate, according to Koppen, is classified as rainy tropical, with annual averages of rainfall, relative humidity and temperature of $1667 \mathrm{~mm}, 70 \%$ and $27.4{ }^{\circ} \mathrm{C}$, respectively, with a rainy period beginning in April and ending in September. The monthly rainfall and average temperature data, collected during the experimental period, are described in Figure 1.
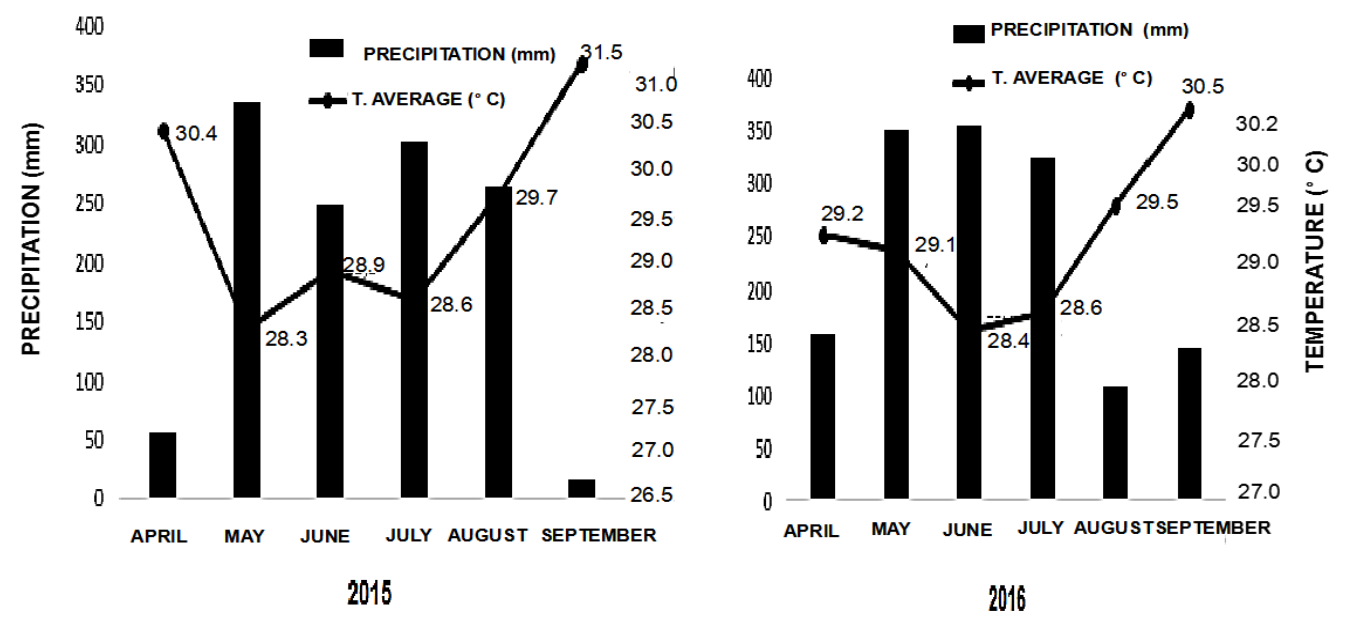

Figure 1. Rainfall and average monthly temperature between the months of April and September of the years 2015 and 2016 in Boa Vista-RR

The soil was classified as dystrophic Yellow Latosol (LAdx) with medium texture (Embrapa, 2013), which presented the physical-chemical attributes in the 0 to $20 \mathrm{~cm}$ layer: $\mathrm{pH}=5.9 ; \mathrm{P}=$ $52.0 \mathrm{mg} \mathrm{dm}{ }^{-3} ; \mathrm{K}^{+}=0.05 \mathrm{cmol}_{\mathrm{c}} \mathrm{dm}^{-3} ; \mathrm{Ca}^{2+}=1.66 \mathrm{cmol}_{\mathrm{c}} \mathrm{dm}^{-3} ; \mathrm{Mg}^{2+}=0.470 \mathrm{cmol}_{\mathrm{c}} \mathrm{dm}^{-3} ; \mathrm{Al}^{3+}=$ $0.03 \mathrm{cmol}_{\mathrm{c} \mathrm{dm}}{ }^{-3} ; \mathrm{H}+\mathrm{Al}^{3+}=1.93 \mathrm{cmol}_{\mathrm{c} \mathrm{dm}}{ }^{-3} ; \mathrm{MO}=12.98 \mathrm{~g} \mathrm{~kg}^{-1} ; \mathrm{CTCt}=1.86 \mathrm{cmol}_{\mathrm{c} \mathrm{dm}}{ }^{-3} ; \mathrm{V}$ $(\%)=49.0 ; \mathrm{m}(\%)=2.0$.

The experimental design was in randomized blocks, in a split-plot scheme, with four replications. The treatments consisted of the association between two years of cultivation: 2015 and 2016 (plot) and four plant densities: 10, 14, 18 and 22 plants per linear meter (subplot), corresponding to populations of 200 to 440 thousand plants per hectare, respectively. The collection area of each experimental unit was composed of eight lines with $5 \mathrm{~m}$ in length, spaced by $0.5 \mathrm{~m}\left(20.0 \mathrm{~m}^{2}\right)$. The useful area consisted of four central lines, totaling $8 \mathrm{~m}^{2}$ (4 m x $2.0 \mathrm{~m}$ ), leaving $0.5 \mathrm{~m}$ at the ends of the collection line, as well as the other lines, as a border (Figure 2). 


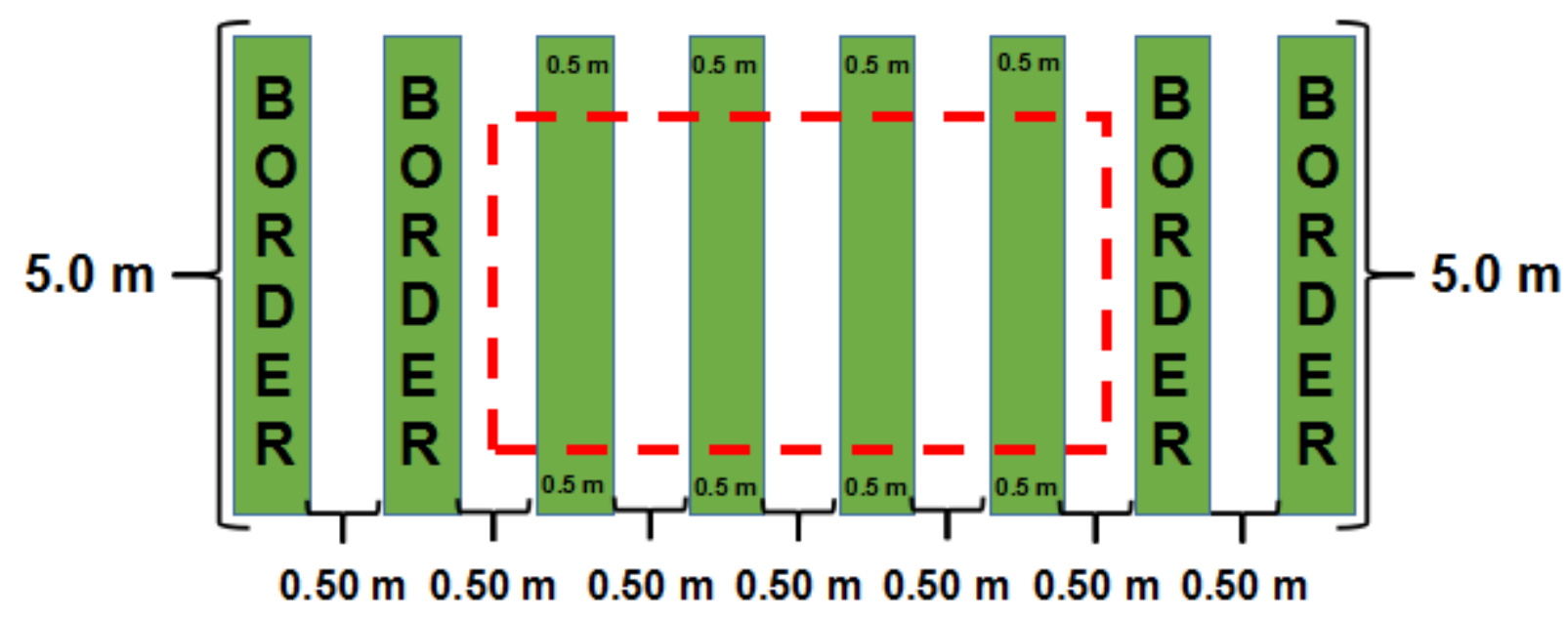

Figure 2. Sketch of an experimental plot showing the layout of the useful area

The seeds were previously treated with fungicides, Derosal Plus and Protreat $(200 \mathrm{~mL} ; 100$ $\mathrm{kg}^{-1}$ of seeds), inoculated with commercial peat inoculant $\left(6\right.$ doses ha- $\left.{ }^{-1}\right)$ and liquid (4 doses $\mathrm{ha}^{-1}$ ), with $5079+5080$ strains and later mechanically sown in furrows $0.05 \mathrm{~m}$ deep. At 10 days after emergence (DAE), thinning of the plants was carried out in the sowing line, leaving the pre-established densities as treatments. The foundation fertilization consisted of the application of $400 \mathrm{~kg} \mathrm{ha}^{-1}$ of the formula $04-28-20$ and $20 \mathrm{~kg} \mathrm{ha}^{-1}$ of micronutrients in the form of FTE BR 12. The cover fertilization was performed at 20 days after sowing and consisted of $200 \mathrm{~kg} \mathrm{ha}^{-1}$ of potassium chloride, applied by haul. The cultural treatments related to the control of pests, diseases and spontaneous plants were done according to the recommendations of Smiderle et al. (2019), for the cultivation of soybeans in the Cerrado of Roraima.

The harvest was carried out at 85 DAE of the seedlings, where 20 plants were initially collected by repetition ( 80 per treatment) manually from the useful area taking them to the Embrapa Roraima seed technology laboratory for further evaluation of agronomic characteristics: Plant height $(\mathrm{PH})$, determined with a ruler graduated in centimeters, taking the distance between the ground level and the apex of the plant; stem diameter (SD), between the soil and the insertion of the first pod, determined by a $0.1 \mathrm{~mm}$ precision digital caliper; Number of nodes on the stem (NNS) was performed by counting from the first true node; Number of branches per plant (NBP), counting the number of branches emitted by each plant, determined at the time of harvest; plant dry mass (PDM), determined by weighing the dried plant material in a forced air oven at $65^{\circ} \mathrm{C}$ for 72 hours. The results were expressed in $\mathrm{g}$; height of insertion of the first pod (HIFP) was measured with the aid of a ruler graduated in centimeters, taking the distance between the ground level and the insertion point of the first pod in the main branch; number of pods per plant (NPP), counting the total number of pods for each plant; dry grain mass (DGM), obtained by weighing the dry grains in a forced air oven at $65{ }^{\circ} \mathrm{C}$, for 72 hours. The results were expressed in g; dry shell mass (DSM), determined by weighing the dry shell (empty pod) in a forced air oven at $65{ }^{\circ} \mathrm{C}$ for 72 hours. The results were expressed in g; apparent harvest index (AHI), obtained by the ratio between the mass of plant grains and the dry mass of the aerial part of the plant. It is worth mentioning 
that the threshing of the pods for the 20 plants was carried out manually. The pods referring to the useful area of the parcel, the threshing was carried out mechanically in a stationary tracker and, soon after, the grains were cleaned in sieves to determine the grain yield estimated as: grain productivity (GP), determined after the harvest, trail and weighing of the useful area of the treatments for each repetition, with the aid of a conventional scale, the values being converted to $\mathrm{kg} \mathrm{ha}^{-1}$, correcting the humidity level to $13 \%$. The data were submitted to analysis of variance, with the level of significance determined by the F test at $5 \%$ probability. The effects of plant densities were verified through polynomial regression analysis using the SISVAR 5.4 software (Ferreira et al., 2018).

\section{Results and Discussion}

\section{Vegetative characteristics of the crop}

The analysis of variance revealed a significant effect for the interaction in plant height (PH), number of nodes in the main stem (NNS) and dry mass of the plant (DMP). Only the density of plants influenced the number of branches per plant (NBP), while in the stem diameter (SD) there was an isolated influence of both factors (Table 1).

Table 1. Summary of analysis of variance for the characteristics of plant height ( $\mathrm{PH})$, stem diameter (SD), number of nodes on the stem (NNS), number of branches per plant (NBP) and plant dry mass (PDM) of 'BRS 8381' soybean cultivated in two years under four plant densities. Boa Vista-RR, 2015 and 2016.

\begin{tabular}{ccccccc}
\hline FV & DF & \multicolumn{5}{c}{ MS } \\
\cline { 3 - 7 } & & PH & SD & NNS & NBP & PDM \\
\hline BLOK & 3 & 19.03 & 0.06 & 0.19 & 0.59 & 1.18 \\
DENSITY (D) & 3 & $25.90^{\mathrm{ns}}$ & $0.73^{* *}$ & $1.62^{* *}$ & $1.72^{* *}$ & $5.20^{* *}$ \\
ERROR 1 & 9 & 9.55 & 0.06 & 0.22 & 0.11 & 0.35 \\
YEAR (A) & 1 & $1606.73^{* *}$ & $2.79^{* *}$ & $3.12^{* *}$ & $0.41^{\mathrm{ns}}$ & $20.70^{* *}$ \\
ERROR 2 & 3 & 1.63 & 0.05 & 0.03 & 0.21 & 0.24 \\
D X Y & 3 & $33.35^{*}$ & $0.08^{\mathrm{ns}}$ & $2.14 *$ & $0.12^{\mathrm{ns}}$ & $0.92^{*}$ \\
ERROR 3 & 9 & 7.07 & 0.05 & 0.35 & 0.07 & 0.18 \\
\hline CV 1\% & & 5.24 & 5.05 & 3.39 & 9.46 & 13.21 \\
CV 2\% & & 2.17 & 4.51 & 1.39 & 13.23 & 2.78 \\
CV 3\% & & 4.51 & 4.29 & 4.24 & 7.82 & 1.69 \\
\hline
\end{tabular}


*** $\mathrm{e}^{\mathrm{ns}}$ - Significant at the level of $5 \%, 1 \%$ and not significant, respectively by the $\mathrm{F}$ test.

Figure 3 outlines the growth in height in relation to plant densities. It was found that soybean plants showed a linear response for the year 2016 as a function of density. For the year 2016, a maximum value of $70.43 \mathrm{~cm}$ in height stands out in response to the density of 22 plants per linear meter. However, for 2015 , there were no significant differences between them, with a general average of $52.00 \mathrm{~cm}$ in growth in height in relation to densities (Figure 3), showing a decrease of $26.16 \%$ in growth when compared to the year 2016. This difference in growth in height between the years 2015 and 2016 is related to the higher rainfall in June 2016, when compared to the year 2015 (Figure 1).

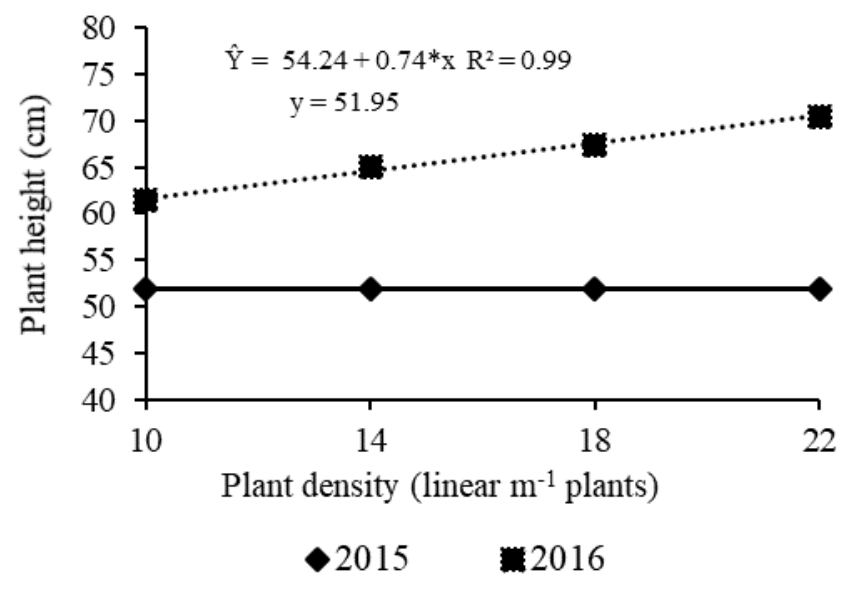

Figure 3. Height of 'BRS 8381' soybean plants as a function of plant density in the row in two years of cultivation

The low level of light, due to the rainy period in June 2016 (Figure 1), caused the cv. BRS 8381 changes the growth habit, promoting a greater number of nodes in the plant stem (Figure 4) and an increase in apical dominance, resulting in larger plants (Figure 3). This allows them to elucidate that the cultivar BRS 8381 is dependent on the interaction between genotype and environment, and this behavior is considered satisfactory considering that the 'BRS 8381' plants have a semi-determined habit (Smiderle et al., 2019).

For the number of nodes in the stem of 'BRS 8381' soybean plants (NNH), a linear decrease was observed in 2015 with an increase in plant density, differing from 2016, where there were no variations between the evaluated densities, which presented an average of around 14 nodes per stem (Figure 4). According to Martorano et al. (2016), each leaf is associated with a node on the stem, which in turn is directly related to the increase in leaf area, which is responsible for the interception of solar radiation used in photosynthesis for the production of photoassimilates.

According to Smiderle et al. (2019), during the cycle, the plant goes through several stages, from V0 (first cotyledonary node) to Vn (last node), and this phase partially overlaps the reproductive phase, between the appearance of the first flower (R1) and the physiological 


\section{Macrothink

maturity (R8), occurring the appearance of nodes during part of the reproductive phase of R1 until the beginning of the formation of the grain (R5), when $\mathrm{Vn}$ is reached.

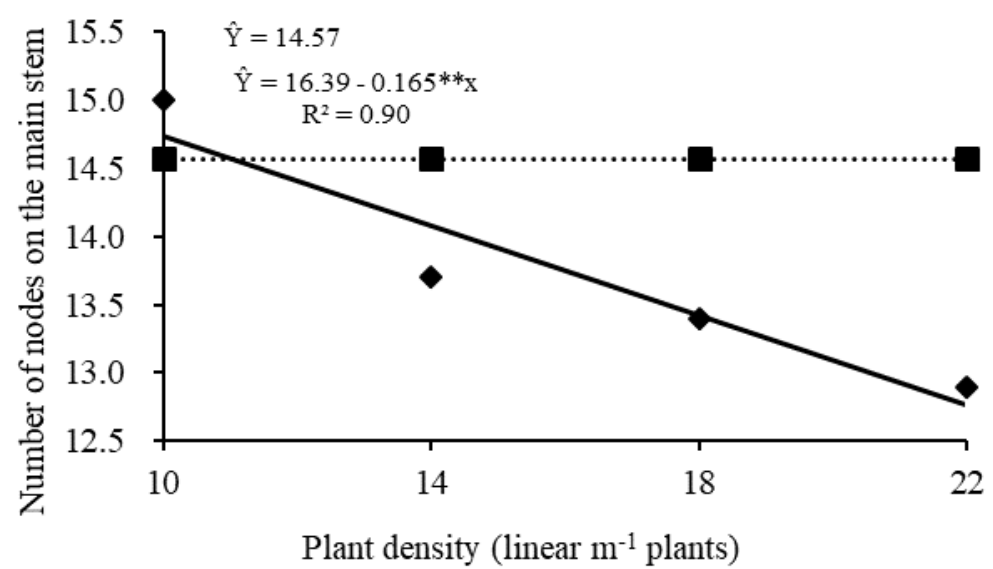

$\bullet 2015 \square 2016$

Figure 4. Number of nodes in the stem of soybean plants 'BRS 8381 ' as a function of plant density in two years of cultivation

Another important component is the stem diameter, which was influenced in isolation by years of cultivation and plant densities. In 2016, it presented a greater increase $(10.72 \%)$ in the stem diameter when compared to the year 2015 (Table 2). This gain in stem diameter is related to abiotic factors such as the highest rainfall (Figure 1) that occurred during that year.

Table 2. Average values of stem diameter of 'BRS 8381' soybean plants in two years of cultivation

\begin{tabular}{cc}
\hline Years of cultivation & Diameter $(\mathrm{mm})$ \\
\hline 2015 & $4.91 \mathrm{~b}$ \\
2016 & $5.50 \mathrm{a}$ \\
\hline Average & 5.20 \\
\hline
\end{tabular}

It is noteworthy that the height growth in relation to the plant densities were determinant for the variable stem diameter, and the higher plant density (22 plants per linear meter) reduced the stem diameter of the 'BRS 8381' soybean plants. According to Smiderle et al. (2019), the diameter of the stem is a characteristic related to the propensity for lodging, a fact that was not observed during the experimental period. 


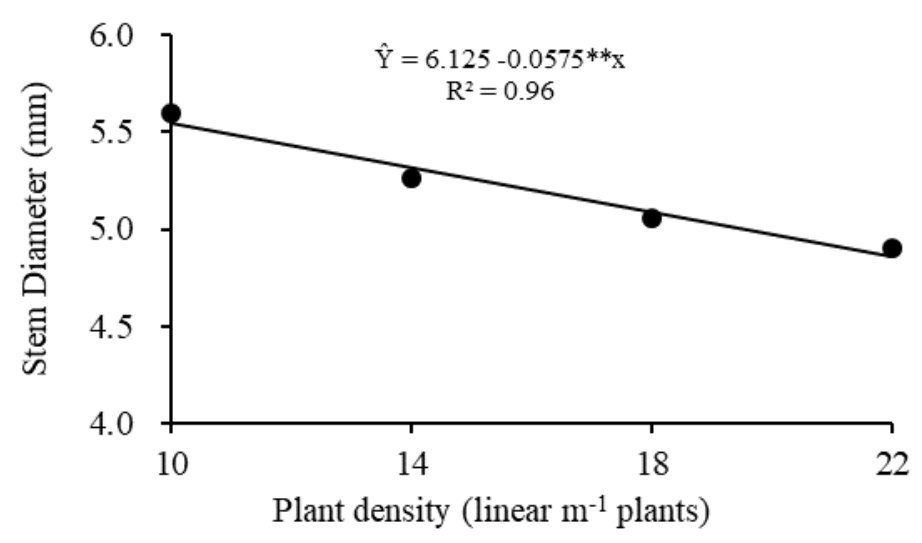

Figure 5. Stem diameter of 'BRS 8381' soybean plants as a function of plant density in two years of cultivation

Regarding the number of branches per plant (NRP), there was an interrelation between the stem diameter and the number of branches per plant, which showed a decreasing linear response for the three variables studied (Figures 3, 5 and 6). Such results stated that with the increase in the number of plants in the line, the growth in height is greater while the stem diameter is reduced and the production of branches decreases, with a minimum of three branches per plant, reached with a density of 22 plants linear meter (Figure 6).

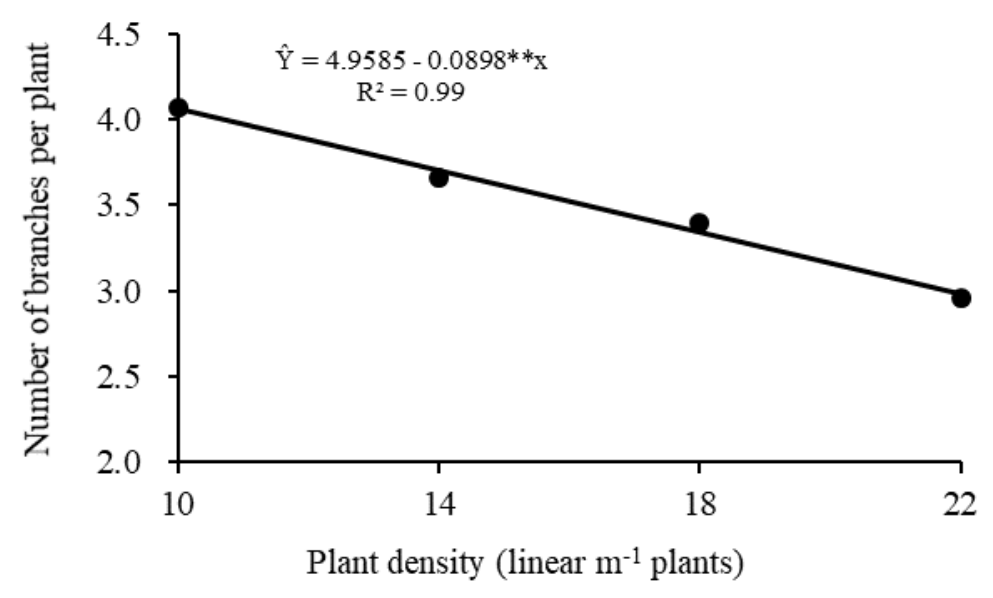

Figure 6. Number of branches per 'BRS 8381 ' soybean plant, depending on plant density in two years of cultivation

In 2015, there was a decreasing linear behavior in the dry mass of the plants as the plant density of the crop increased, with a greater accumulation of phytomass in the lower densities in both years (Figure 7). However, in 2016, the dry plant mass of 'BRS 8381' at densities 14 and 18 plants per linear meter (Figure 7), showed a strong downward trend, which is mainly related to the net assimilation rate that decreases with reduced light flow. Thus, the plants of the present research were directly influenced by extrinsic factors of the environment. 


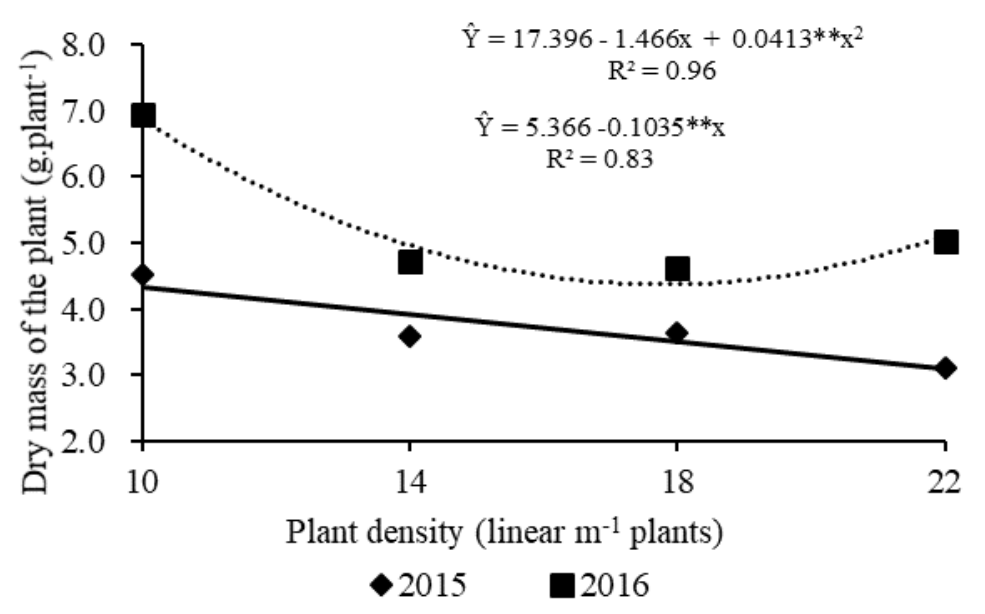

Figure 7. Dry mass of the 'BRS 8381 ' soybean plant $\left(\mathrm{g} \mathrm{plant}^{-1}\right)$, as a function of plant density in two years of cultivation

(2013), working with soybean cultivars, of semi-determined growth, varying the spacing between rows, both in single and double rows, verified higher production of dry matter of the aerial part in plants cultivated with 200.000 plants $\mathrm{ha}^{-1}$, compared to those cultivated with 400.000 plants ha $^{-1}$.

Productive characteristics of $c v$. BRS 8381 as a function of plant density in two years of cultivation

Table 3 shows the summary of the analysis of variance of the data obtained for the productive characteristics of the cultivar BRS 8381. With the results, it was observed that the density of plants per linear meter and the year of cultivation are found together on the number of pods per plant and on the dry mass of the grains. There was no significant effect of treatments on the apparent harvest index. For the other characteristics studied, only isolated effects of the factors were observed. 
Table 3. Summary of analysis of variance for the characteristics of height of first pod insertion (HFPI), number of pods per plant (NPP), dry mass of grains (DMG), dry mass of husk (DMH), apparent harvest index (AHI) and grain yield (GY) of 'BRS 8381' soybeans grown in two years under four plant densities, Boa Vista-RR, 2015 and 2016

\begin{tabular}{cccccccc}
\hline FV & DF & \multicolumn{7}{c}{ MS } \\
\cline { 3 - 8 } & & HFPI & NPP & DMG & DMH & AHI & GY \\
\hline BLOK & 3 & 0.32 & 18.75 & 6.09 & 1.14 & 0.00022 & 17156.40 \\
DENSITY (D) & 3 & $0.86^{* *}$ & $494.09^{* *}$ & $89.92^{* *}$ & $9.53^{* *}$ & $0.00007^{\mathrm{ns}}$ & $2570128.73^{* *}$ \\
ERROR 1 & 9 & 0.10 & 17.59 & 3.05 & 0.49 & $0.00015^{*}$ & 50493.45 \\
YEAR (A) & 1 & $5.00^{*}$ & $1.97^{\mathrm{ns}}$ & $33.64^{* *}$ & $0.76^{\mathrm{ns}}$ & $0.00125^{\mathrm{ns}}$ & $557773.93^{* *}$ \\
ERROR 2 & 3 & 0.21 & 9.55 & 0.90 & 0.26 & 0.00022 & 15011.52 \\
D X A & 3 & $0.52^{\mathrm{ns}}$ & $37.41^{*}$ & $7.33^{*}$ & $0.28^{\mathrm{ns}}$ & $0.00005^{\mathrm{ns}}$ & $341890.73^{\mathrm{ns}}$ \\
ERROR 3 & 9 & 0.32 & 7.99 & 1.81 & 0.32 & 0.00011 & 58290.11 \\
\hline CV 1\% & & 3.18 & 8.98 & 9.58 & 11.42 & 1.93 & 5.51 \\
CV 2\% & & 4.62 & 6.62 & 5.21 & 8.37 & 2.37 & 3.05 \\
\hline CV 3\% & & 5.62 & 6.05 & 7.39 & 9.26 & 1.66 & 5.92 \\
\hline
\end{tabular}

${ }^{*} *^{* *} \mathrm{e}^{\mathrm{ns}}-$ Significant at the level of $5 \%, 1 \%$ and not significant respectively by the $\mathrm{F}$ test.

The height of insertion of the first pod was influenced by the years of cultivation, where 2016 was responsible for the highest average observed. This result may have been due to the higher rainfall (Figure 1) during 2016. Knowing the height of the insertion of the first pod and the architecture of the soybean plants, these are genetically defined characteristics, which, however, can be influenced by several factors, such as sowing time, spacing, plant density, water supply, air temperature and soil fertility (Menezes et al., 2019). Thus, observing the values of temperature and rainfall that occurred in the two years of cultivation, it was found that the year 2015 had a higher average of high temperatures and less rainfall in relation to the year of cultivation 2016 (Figure 1). This alteration in the microclimate leads to postulate that the plants of the present research were directly influenced by abiotic factors, with a greater height of insertion of the first pod in 2016 (Table 4). 


\section{IIMacrothink}

Table 4. Average values of the height of insertion of the first pod (HIFP) in soybean plants 'BRS 8381' in two years of cultivation

\begin{tabular}{cc}
\hline Years of cultivation & HIFP $(\mathrm{cm})$ \\
\hline 2015 & $9.71 \mathrm{~b}$ \\
2016 & $10.50 \mathrm{a}$ \\
\hline Average & 10.10 \\
\hline
\end{tabular}

Such data in figure 8 indicate the full morphological potential under conditions of plant density, showing a significant and superior effect on the height of insertion of the first pod (HIVP), when compared between the years of cultivation (Table 4). In agreement with the data obtained by Mauad et al. (2010), in which the increase in plant density caused, as expected, an increase in the height of insertion of the first pod.

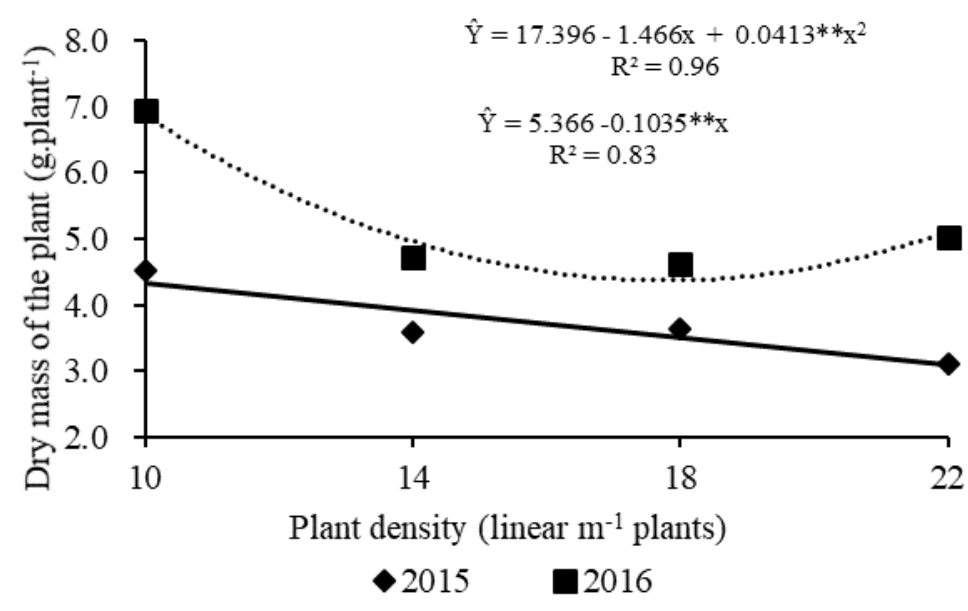

Figure 8. Height of insertion of the first pod of 'BRS 8381' soybean plants as a function of plant density in two years of cultivation

This result is associated with plant height data (Figure 3) presented above, since taller plants tend to have fewer branches (Figure 4), consequently less pods (Figure 9). On the other hand, there is synchronization of the life cycle with the limitations imposed by the environment (Figure 1), directly interfering in the agronomic attributes of the 'BRS 8381' soybean, as shown in Figure 9 for the variable number of pods per plant in 2016, which exhibited 37\% less when compared to 2015 in the density of 22 plants per linear meter. 


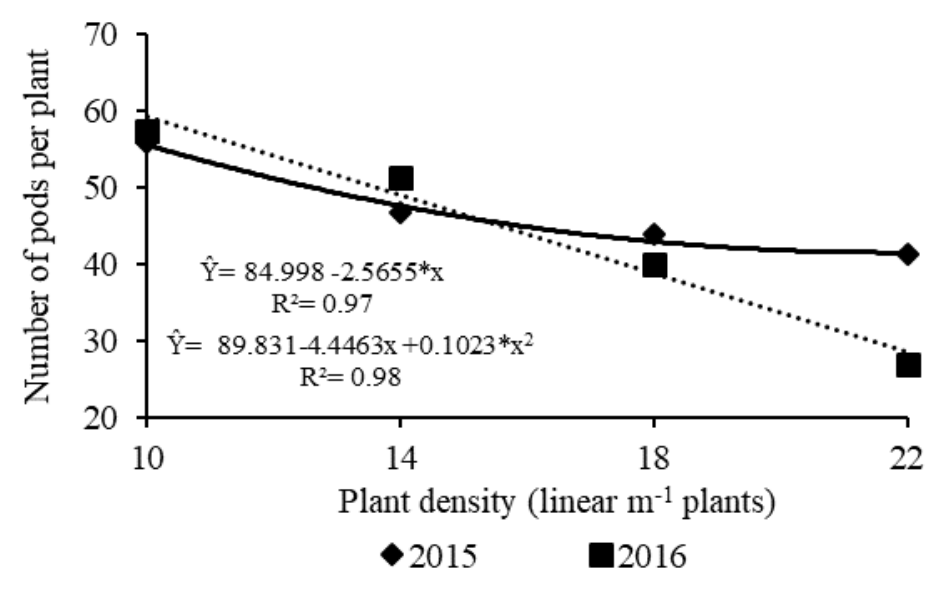

Figure 9. Number of pods per 'BRS 8381' soybean plant, depending on plant density in two years of cultivation

In relation to the dry grain mass for the year 2016, a maximum value of $25.48 \mathrm{~g} \mathrm{plant}^{-1}$ was observed in response to the density of 10 plants per linear meter $\left(200.000\right.$ plant $\left.\mathrm{ha}^{-1}\right)$, however, in 2015, a maximum value of $20.86 \mathrm{~g} \mathrm{plant}^{-1}$ was obtained at the same density (Figure 10).

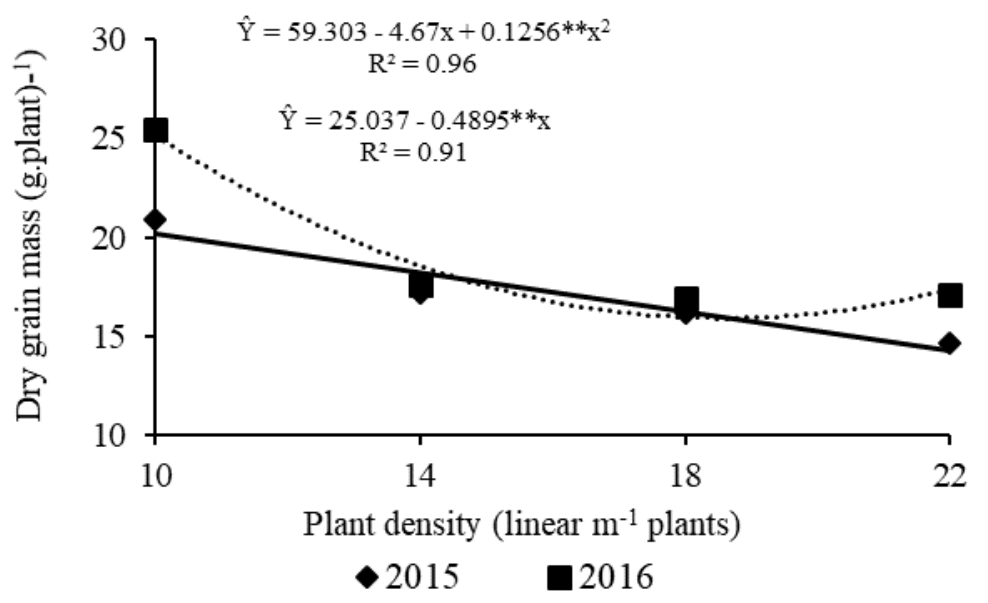

Figure 10. Dry mass of grains ( $\mathrm{g} \mathrm{plant}^{-1}$ ) of 'BRS 8381' soybean, as a function of plant density in two years of cultivation

The dry mass of grains in the year 2016 showed an increase of 19\% in relation to the year 2015 (Figure 11). What may have favored the increase in this percentage in 2016 was due to the number of plants in the line, under these conditions, allowing greater spacing between plants and consequently greater interception of light and $\mathrm{CO}_{2}$ absorption and certainly greater mobilization of nutritional reserves, for the grains promoted by photosynthesis. 


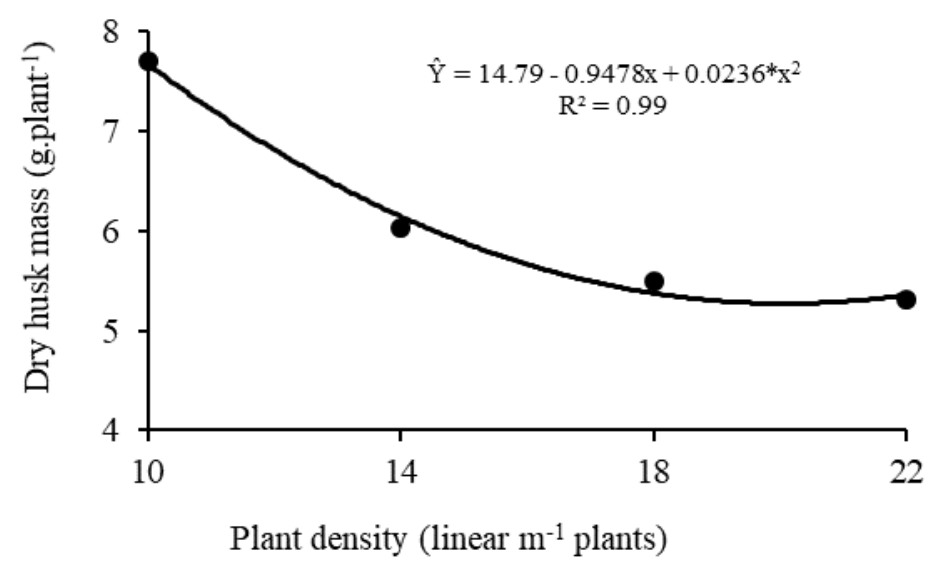

Figure 11. Dry mass of soybean husk 'BRS 8381', as a function of plant density in two years of cultivation

Although changes in the preferred metabolic drain occur, it is noted that the dry mass of the bark (Figure 11) in relation to the plant densities showed an interrelation with the dry mass of grains (Figure 10) in the different plant densities per linear meter for both years of cultivation.

In addition, the modification of the distribution of assimilates in different useful parts, through practices and management of the environment, thus constitutes, potentially, a way to increase agricultural productivity. Related results allow us to suggest with greater credibility that grain productivity was influenced by the years of cultivation, where 2016 was responsible for obtaining a higher average (Figure 12). For grain productivity there was a quadratic behavior, as the density of plants increased, there was an increase in productivity, up to a density of 19.37 plants $\mathrm{m}^{-1}$ linear, with a subsequent decrease with an increase in plant density (Figure 12).

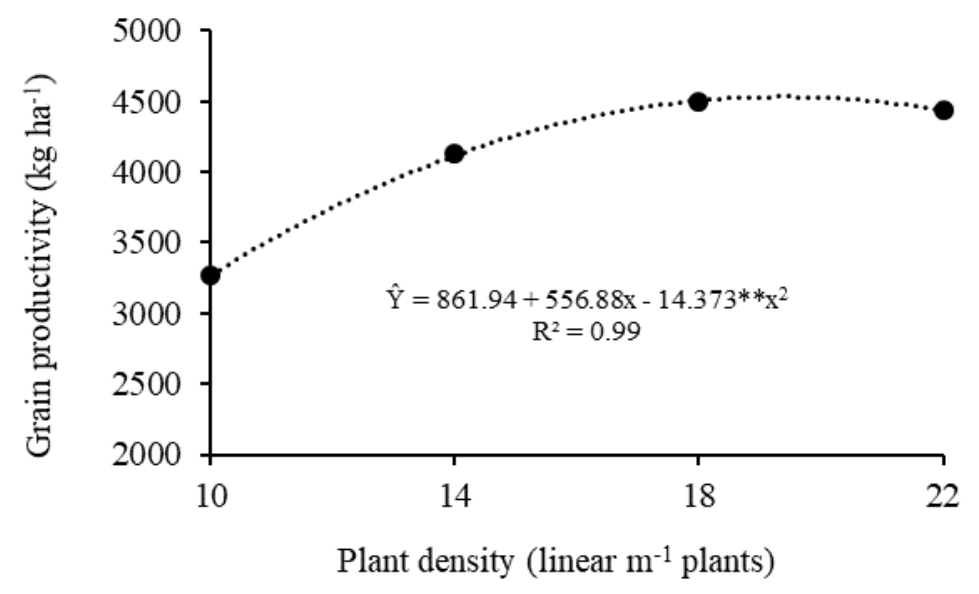

Figure 12. Productivity of 'BRS 8381' soybeans, as a function of plant density in the row in two years of cultivation 
In short, the distribution of radiant energy within the plants of cv. BRS 8381 up to the density of 19.37 linear $\mathrm{m}^{-1}$ plants is considered adequate for filling the grains, making them highly efficient mobilizing drains for assimilates, directly influencing productivity (Figure 11). Thus making it a viable measure of agronomic efficiency for the studied cultivar. In contrast, 'BRS 8381' plants with a density of 22 linear $\mathrm{m}^{-1}$ plants, reinforce the assumption that the distribution of solar radiation in these conditions of the Cerrado of Roraima was not adequate for the promotion of photosynthetic rates in order to influence the decrease in grain productivity of 'BRS 8381' (Figure 12).

This behavior exhibited by the plants of 'BRS 8381 ' at the density of 22 plants $\mathrm{m}^{-1}$ linear, allows suggesting with greater credibility that the greater density is an unnecessary practice that, in addition to not increasing grain productivity can reduce it, in some circumstances, especially in cultivars that are prone to lodging.

\section{Conclusions}

1. The highest average productivity of 'BRS 8381 ' soybeans in the Cerrado area of Roraima is obtained with a population of 387.448 plants per hectare or 19.37 plants per linear meter.

2. 'BRS 8381 ' plants at density 22 plants $\mathrm{m}^{-1}$ linear are not suitable for the Cerrado conditions of Roraima.

3. The cv. BRS 8381 is influenced by the factors, rainfall and temperature in the Cerrado conditions of Roraima in the two years of cultivation.

4. 'BRS 8381' plants with a density of 10 plants per linear meter show gains in aerial part biomass production under the conditions of the Cerrado of Roraima in 2016.

5. The low level of light in June 2016 promotes a change in the growth habit of 'BRS 8381' in the conditions of the Cerrado of Roraima.

6. The 'BRS 8381' plants, regardless of density and year of cultivation in the conditions of the Cerrado of Roraima, are not prone to lodging.

\section{References}

Bawa, S., Quansah, C., Tuffour, H., Abubakari, A., \& Melenya, C. (2019). Root Growth Responses of Maize (Zea mays L.) and Soybean (Glycine max L.) to Soil Compaction and Fertilization in a Ferric Acrisol. Journal of Experimental Agriculture International, 35(3), 1-11, 2019. https://doi.org/10.9734/jeai/2019/v35i330207

Ferreira, E. B., Cavalcanti, P. P., \& Nogueira, D. A. (2018). Package 'ExpDes.pt': Experimental Designs. R package version 1.2.0.62p.

Martorano, L. G., Siviero, M. A., Monteiro, T, D. C., Vieira, S. B., Fitzjarrald, D. R., Vettorazzi, C. A., \& Lisboa, L. S. S. (2016). Agriculture and forest: A sustainable strategy in the Brazilian Amazon. Revista Australian Journal of Crop Science, 10 (8), 1136. https://doi.org/10.21475/ajcs.2016.10.08.p7727 


\section{Macrothink}

Mauad, M., Silva, T. L. B., Almeida Neto, A. I., \& Abreu, V. G. (2010). Influência da densidade de semeadura sobre características agronômicas na cultura da soja. Revista Agraria, 3(9), 175-181. http://ojs.ufgd.edu.br/index.php/agrarian/article/view/75

Menezes, P. H. S., Albuquerque, J. A. A., Smiderle, O., Medeiros, R. D., Alves, J. M. A., \& Gianluppi, D. (2019). Occurrence of weeds in areas submitted to tillage managements for soybean cultivation in the cerrado of Roraima. Planta Daninha, 37:e019193014. https://doi.org/10.1590/s0100-83582019370100079

Nakano, S., Purcell, L. C., Homma, K., \& Shiraiwa, T. (2019). Modeling leaf area development in soybean (Glycine max L.) based on the branch growth and leaf elongation. Plant Production Science, 2(3), 1-13. https://doi.org/10.1080/1343943X.2019.1702468

Procópio, S. de O., Junior, A. A. B., Debiasi, H., Santos, J. C. F., \& Panison, F. (2013). Plantio cruzado na cultura da soja utilizando uma cultivar de hábito de crescimento indeterminado. Revista Ciência Agrarias, 56 (4) 319-325. https://doi.org/10.4322/rca.2013.048

Prysiazhniuk, L., Shytikova,Y., Dikhtiar, I., \& Mizerna, N. (2019). Evaluation of genetic and morphological distances between soybean (Glycine max L.) cultivars. Zemdirbyste-Agriculture, 106(2), 117-122. https://doi.org/10.13080/z-a.2019.106.015

Smiderle, O. J., Gianluppi, D., \& Souza, A.G. (2016). Variability among 'BRS 8381' soybean (Glycine $\max$ (L.) Merrill.) yield components under different liming rates and sowing densities on a savanna in Roraima, Brazil. Revista Colombiana de Investigaciones Agroindustriales, 2(1), 49-55. https://doi.org/10.23850/24220582.350

Smiderle, O. J., Souza, A. G., Gianluppi, V., Gianluppi, D., Costa, K. N. A., \& Silva Gomes, H. H. S. (2019). Correlação entre componentes de produção de soja 'BRS tracajá' e diferentes densidades de plantas no cerrado Roraima. Revista Brasileira de Agropecuária Sustentável, 9(1), 34-40. https://doi.org/10.21206/rbas.v9i1.3065

\section{Copyright Disclaimer}

Copyright for this article is retained by the author(s), with first publication rights granted to the journal.

This is an open-access article distributed under the terms and conditions of the Creative Commons Attribution license (http://creativecommons.org/licenses/by/4.0/). 